\title{
Temporal Variations of ${ }^{7} \mathrm{Be}$ and ${ }^{210} \mathrm{~Pb}$ Activity Concentrations in the Atmosphere and Aerosol Deposition Velocity in Shenzhen, South China
}

\author{
Guoqing Liu ${ }^{1 *}$, Jiabao $\mathrm{Wu}^{1}$, Yong $\mathrm{Li}^{1}$, Lingling Su${ }^{2}$, Minxia Ding ${ }^{3}$ \\ ${ }^{1}$ Department of Nuclear Science and Technology, College of Physics and Opotoelectronic Engineering, Shenzhen \\ University, Shenzhen 518060, China \\ ${ }^{2}$ Center for Advanced Materials Diagnostic Technology, Shenzhen Technology University, Shenzhen 518118, China \\ ${ }^{3}$ Shenzhen Environmental Monitoring Center, Shenzhen 518049, China
}

\begin{abstract}
Naturally occurring beryllium-7 $\left({ }^{7} \mathrm{Be}\right)$ and lead-210 $\left({ }^{210} \mathrm{~Pb}\right)$ serve as powerful tracers in atmospheric studies. In this study, ${ }^{7} \mathrm{Be}$ and ${ }^{210} \mathrm{~Pb}$ were simultaneously measured in atmospheric aerosols and deposition samples for an entire year (from January to December 2017) in Shenzhen, South China. The activity concentrations of the airborne ${ }^{7} \mathrm{Be}$ and ${ }^{210} \mathrm{~Pb}$ ranged from 0.33 to $9.42 \mathrm{mBq} \mathrm{m}^{-3}$ (averaging $3.23 \mathrm{mBq} \mathrm{m}^{-3}$ ) and from 0.59 to $4.72 \mathrm{mBq} \mathrm{m}^{-3}$ (averaging $1.58 \mathrm{mBq} \mathrm{m}^{-3}$ ), respectively, and were observed to be high during the winter but low during the summer. Moreover, the relatively high ${ }^{210} \mathrm{~Pb}$ concentration was probably due to the elevated level of radon in this region's soil. The deposition fluxes of the ${ }^{7} \mathrm{Be}$ and ${ }^{210} \mathrm{~Pb}$ were found to range from 0.25 to $3.04 \mathrm{~Bq} \mathrm{~m}^{-2}$ day $^{-1}$ (averaging $1.57 \mathrm{~Bq} \mathrm{~m}^{-2}$ day $^{-1}$ ) and from 0.34 to $1.31 \mathrm{~Bq} \mathrm{~m}^{-2}$ day $^{-1}$ (averaging $0.73 \mathrm{~Bq} \mathrm{~m}^{-2}$ day $\left.^{-1}\right)$, respectively. The temporal trends of these fluxes were largely influenced by rainfall and the origin and pathway of air masses, as well as by atmospheric circulation. Based on their concentrations in the aerosols and their deposition fluxes, the average deposition velocities of ${ }^{7} \mathrm{Be}$ and ${ }^{210} \mathrm{~Pb}$ were calculated to be 0.83 and $0.62 \mathrm{~cm} \mathrm{~s}{ }^{-1}$, respectively. The deposition velocities of both radionuclides correlated well with the amount of rainfall, indicating that precipitation plays a crucial role in removing ${ }^{7} \mathrm{Be}$ and ${ }^{210} \mathrm{~Pb}$ from the air. The activity size distributions of these nuclides combined with the characteristic meteorological conditions in this region resulted in high deposition velocities during summer and low ones during winter.
\end{abstract}

Keywords: ${ }^{7} \mathrm{Be}$ and ${ }^{210} \mathrm{~Pb}$; Activity concentrations; Deposition fluxes; Deposition velocity of aerosols; Shenzhen.

\section{INTRODUCTION}

Airborne particles (aerosols) have become the major air pollutant in Chinese megacities (Liu et al., 2014). As long as these particles are formed or injected into the atmosphere, they tend to get involved in physical and chemical processes in the atmosphere (Ahmed et al., 2004) and ultimately sink into the terrestrial environment through dry and wet deposition. Atmospheric particles are considered the main carriers of airborne pollutants and play a crucial role both in air quality and deposition fluxes of pollutants to the earth's surface, which pose a negative effect on the ecological system and human health (Chameides et al., 1999; Yadav et al., 2003). To determine the transport pathway of these pollutants and to assess their environmental impact, it is essential to understand the dynamics of these airborne particles. The naturally

\footnotetext{
* Corresponding author.

Tel.: +86755 26536232; Fax: +86755 26534374

E-mail address: liugq@szu.edu.cn
}

occurring beryllium-7 $\left({ }^{7} \mathrm{Be}\right)$ and lead-210 $\left({ }^{210} \mathrm{~Pb}\right)$ serve as powerful tracers for atmospheric studies that include (i) air mass exchange between the stratosphere and troposphere, (ii) residence times of atmospheric aerosols, (iii) washout ratios and deposition velocity of aerosols, and (iv) source tracking of oceanic and continental air masses (Baskaran, 2011).

${ }^{7} \mathrm{Be}\left(\mathrm{T}_{1 / 2}=53.3\right.$ days $)$ is a cosmogenic radionuclide produced by the reaction of cosmic rays with oxygen and nitrogen atoms in the stratosphere and upper troposphere (Alonso-Hernández et al., 2014); the production rate of ${ }^{7} \mathrm{Be}$ on the earth's surface for a given latitude is independent of longitude (McNeary and Baskaran, 2003). Generally, the airborne concentration of ${ }^{7} \mathrm{Be}$ increases with altitude and is sensitive to meteorological conditions, such as temperature and precipitation (Gai et al., 2015). A high ${ }^{7} \mathrm{Be}$ concentration in ambient air would indicate a large input from the upper atmosphere (Dueñas et al., 2011a). At mid-latitude, the specific concentrations of ${ }^{7} \mathrm{Be}$ exhibit high values in spring, owing to the seasonal contraction of tropopause, which results in the enhancement of air exchange between the stratosphere and troposphere (Ali et al., 2011; Gai et al., 2015). ${ }^{210} \mathrm{~Pb}$ 
$\left(\mathrm{T}_{1 / 2}=22.3\right.$ years $)$ is a naturally occurring radionuclide, originating from the decay of ${ }^{222} \mathrm{Rn}\left(\mathrm{T}_{1 / 2}=3.8\right.$ days $)$. Because ${ }^{222} \mathrm{Rn}$ is mainly emanated from the earth's surface, ${ }^{210} \mathrm{~Pb}$ is considered a tracer of continental air masses (Baskaran, 2011). Once produced, ${ }^{7} \mathrm{Be}$ and ${ }^{210} \mathrm{~Pb}$ instantaneously and irreversibly attach themselves mainly to fine particulates and are removed from air through radioactive decay, dry and wet deposition (Ali et al., 2011). Because of distinctly different sources, combined measurements of ${ }^{7} \mathrm{Be}$ and ${ }^{210} \mathrm{~Pb}$ provide a powerful tool to study the mechanisms of atmospheric processes. Furthermore, knowledge of these nuclides can help us understand the behavior of other similar contaminants in the air (McNeary and Baskaran, 2003).

To date, extensive studies on ${ }^{7} \mathrm{Be}$ and ${ }^{210} \mathrm{~Pb}$ in atmospheric deposition as well as in aerosols have been conducted worldwide (Ioannidou et al., 2005; Alonso-Hernández et al., 2014; Du et al., 2015; Gai et al., 2015; Grossi et al., 2016; Chham et al., 2017; Dueñas et al., 2017). However, combined measurements of ${ }^{7} \mathrm{Be}$ and ${ }^{210} \mathrm{~Pb}$ in aerosols and in bulk fallout are still limited. Located at the eastern side of the Pearl River Delta (PRD) region in Guangdong Province, South China, Shenzhen is a demonstration/pilot zone for socialism with Chinese characteristics, with an area of $2,021 \mathrm{~km}^{2}$ and a population approaching 20 million (Liu et al., 2015). During the past three decades, Shenzhen has made rapid economic progress and has become one of the most important industrial and economic centers in China. The rapid urbanization and industrial development in Shenzhen and the PRD region have placed considerable pressure on the environment. Many studies have been conducted on air pollution in the PRD region, mostly focused on atmospheric particulate matter, heavy metals, and organic pollutants (Liu et al., 2014). However, few studies have been conducted on the atmospheric radiotracers (e.g., ${ }^{7} \mathrm{Be}$ and ${ }^{210} \mathrm{~Pb}$ ) in this region; these studies can provide insights into the mechanism of various atmospheric processes. Shenzhen features a subtropical monsoon climate, with oceanic monsoon prevailing in summer and continental monsoon prevailing in winter. The coastal or continental air masses carry the long-range-transported air pollutants to this region, particularly in winter seasons. Shenzhen thus serves as an ideal region for studying air mass transfer in the subtropical monsoon climate region.

The objectives of the current study were as follows: (1) to determine the temporal variations of ${ }^{7} \mathrm{Be}$ and ${ }^{210} \mathrm{~Pb}$ in atmospheric aerosols in Shenzhen; (2) to study the seasonal deposition fluxes of ${ }^{7} \mathrm{Be}$ and ${ }^{210} \mathrm{~Pb}$ in this region; (3) to investigate factors controlling ${ }^{7} \mathrm{Be}$ and ${ }^{210} \mathrm{~Pb}$ in aerosols and deposition fluxes; and (4) to evaluate the deposition velocity of aerosols using ${ }^{7} \mathrm{Be}$ and ${ }^{210} \mathrm{~Pb}$.

\section{EXPERIMENT METHODS}

\section{Sampling and Preparation}

Air sampling was performed in Shenzhen University (Fig. 1), which is located in the Nantou Peninsula of Shenzhen city. The roof of the experimental building at Shenzhen University $\left(22.5^{\circ} \mathrm{N}, 113.9^{\circ} \mathrm{E}\right)$ was selected as the sampling site. From January to December 2017, atmospheric deposition (wet + dry) samples were collected at monthly intervals by using a stainless container (0.55-m diameter and 0.6-m height). At the end of each collection, bulk fallout samples were transferred to a pre-cleaned polyethylene vessel, the container was washed with $0.2 \mathrm{M} \mathrm{HCl}$ and Milli-Q water to remove ${ }^{7} \mathrm{Be}$ and ${ }^{210} \mathrm{~Pb}$ that are possibly adsorbed on the wall, and the combined solution was adjusted to $\mathrm{pH} 2.0$ with $6 \mathrm{M} \mathrm{HCl}$. ${ }^{7} \mathrm{Be}$ and ${ }^{210} \mathrm{~Pb}$ were obtained through chemical co-precipitation

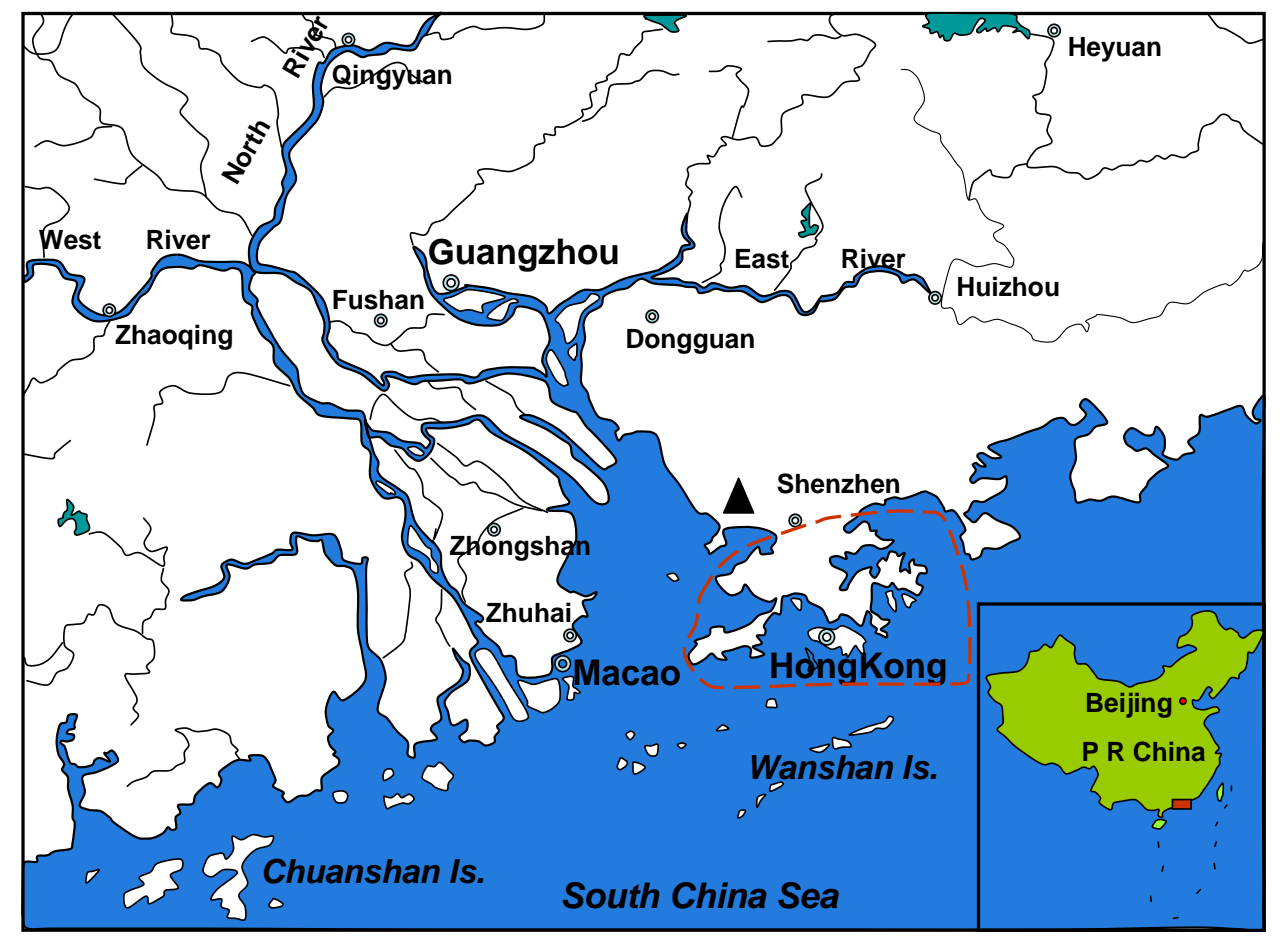

Fig. 1. Sampling location in Shenzhen, South China. 
as described by Du et al. (2008). A known amount of $\mathrm{Fe}^{3+}$ carrier was added to the solution, and after $24 \mathrm{~h}$, the solution was adjusted to $\mathrm{pH} 8.5$ with $\mathrm{NH}_{4} \mathrm{OH}$ for $\mathrm{Fe}(\mathrm{OH})_{3}$ precipitation. The precipitate was then centrifuged and transferred into a cylindrical polyethylene container $(7.5 \mathrm{~cm} \times 7.0 \mathrm{~cm})$ for gamma-ray measurement after drying.

Concurrently, atmospheric aerosol samples were collected once per week using a high-volume air sampler following the procedure described in our previous work (Liu et al., 2010). The sampling flow rate was $1.05 \mathrm{~m}^{3} \mathrm{~min}^{-1}$, and the sampling time for each sample was $24 \mathrm{~h}$; suspended particulates were retained on a Whatman glass microfiber filter (GFF; grade $\mathrm{GF} / \mathrm{A}, 20.3 \mathrm{~cm} \times 25.4 \mathrm{~cm}$ ). After each sampling, filters were folded and pressed into a cylindrical polyethylene container $(7.5 \mathrm{~cm} \times 7.0 \mathrm{~cm})$ so that all samples had the same irradiation geometry.

\section{Analytical Methods}

The activity concentrations of ${ }^{7} \mathrm{Be}$ and ${ }^{210} \mathrm{~Pb}$ were determined through gamma spectrometry; the methodology was described in Liu et al. (2015). Briefly, the gamma spectrometer was equipped with an HPGe detector (GEM-C5970; ORTEC, USA), with an energy resolution of $1.8 \mathrm{keV}$ at the 1.332 $\mathrm{MeV}$ of ${ }^{60} \mathrm{Co}$ and the relative efficiency of $38 \%$. The detector was enclosed in a cylindrical lead shield with $10-\mathrm{cm}$ thickness and $38-\mathrm{cm}$ height. The counting efficiencies of ${ }^{7} \mathrm{Be}$ and ${ }^{210} \mathrm{~Pb}$ in filter and deposition samples were calibrated by an aerosol reference material (QRJH1204, containing ${ }^{152} \mathrm{Eu}$ and ${ }^{137} \mathrm{Cs}$ ) and a soil reference material (7NTR141201, containing ${ }^{238} \mathrm{U}$, ${ }^{235} \mathrm{U},{ }^{226} \mathrm{Ra},{ }^{232} \mathrm{Th},{ }^{40} \mathrm{~K},{ }^{241} \mathrm{Am},{ }^{137} \mathrm{Cs}$ and ${ }^{60} \mathrm{Co}$ ), respectively. The efficiency curves were constructed based on the fullenergy peak efficiencies of these calibrated radionuclides in a cylindrical geometry $(\varnothing 75 \mathrm{~mm} \times 70 \mathrm{~mm})$. According to the sample-to-detector geometry, the true coincidence summing effect for the efficiency calibration with ${ }^{152} \mathrm{Eu}$ was small and could be neglected. ${ }^{7}$ Be activity was determined through its $477.6 \mathrm{keV}$ gamma-ray (yield $10.12 \%$ ), and ${ }^{210} \mathrm{~Pb}$ content through its $46.5 \mathrm{keV}$ gamma-ray (yield $4.25 \%$ ). The counting time was set as $24 \mathrm{~h}$ for all the samples. The GammaVision 32 software was used for the data analysis.

The activity concentrations $(C)$ of ${ }^{7} \mathrm{Be}$ and ${ }^{210} \mathrm{~Pb}$ were calculated as follows:

$$
C_{\mathrm{Pb} / \mathrm{Be}}=\frac{N_{s}-N_{\mathrm{b}}}{\varepsilon \cdot \delta \cdot V}
$$

where $N_{s}$ and $N_{b}$ are the counting rates (in s ${ }^{-1}$ ) of the sample and background, respectively; $\varepsilon$ is the characteristic peak efficiency; $\delta$ is the branching ratio; and $V$ is the sample volume of aerosol (in $\mathrm{m}^{3}$ ). The total deposition fluxes $(F)$ of ${ }^{7} \mathrm{Be}$ and ${ }^{210} \mathrm{~Pb}$ were determined as follows:

$$
F=\frac{A_{\mathrm{Be} / P b}}{S \cdot T}
$$

where $A_{\mathrm{Be} / \mathrm{Pb}}$ is the total activity of ${ }^{7} \mathrm{Be}$ and ${ }^{210} \mathrm{~Pb}$ (in $\mathrm{Bq}$ ) deposited in the collector; $S$ is the total surface area of the collector (in $\mathrm{m}^{2}$ ); and $T$ is the sampling duration (in days).
The final activity of ${ }^{7} \mathrm{Be}$ was radioactive decay corrected for the time interval between the sampling and measurement, whereas it was not performed for ${ }^{210} \mathrm{~Pb}$ due to its relatively long half-life.

\section{RESULTS AND DISCUSSION}

\section{${ }^{7} \mathrm{Be}$ and ${ }^{210} \mathrm{~Pb}$ activity Concentration in the Air}

During the sampling period from January to December 2017, the weekly activity concentration of ${ }^{7} \mathrm{Be}$ was in the range of $0.33-9.42 \mathrm{mBq} \mathrm{m}^{-3}$, with an annual average of $3.23 \mathrm{mBq} \mathrm{m}^{-3}$. These values were comparable with those obtained from near-surface atmospheric aerosols reported in low-latitude regions, such as Guangzhou, China $\left(2.59 \mathrm{mBq} \mathrm{m}^{-3}\right.$; Pan et al., 2011), but lower than those reported from mid-latitude regions such as Beijing, China $\left(8.39 \mathrm{mBq} \mathrm{m}^{-3}\right.$; Tan et al., 2013); Malaga, Spain (4.6 mBq m ${ }^{-3}$; Dueñas et al., 2011b); Detroit, Michigan $\left(4.8 \mathrm{mBq} \mathrm{m}^{-3}\right.$; McNeary and Baskaran, 2003); and Brindisi, Italy (5.4 $\mathrm{mBq} \mathrm{m}^{-3}$; Hernández-Ceballos et al., 2015). The activity concentration of ${ }^{210} \mathrm{~Pb}$ was in the range of $0.59-4.72 \mathrm{mBq} \mathrm{m}^{-3}$, with an annual average of $1.58 \mathrm{mBq} \mathrm{m}^{-3}$. These values were similar to those reported in the northern cities of China (Li et al., 2013) but higher than in Kumamoto, Japan $\left(0.89 \mathrm{mBq} \mathrm{m}^{-3}\right.$; Momoshima et al., 2006); Malaga, Spain (0.58 $\mathrm{mBq} \mathrm{m}^{-3}$; Dueñas et al., 2011b); and Detroit, Michigan (1.15 $\mathrm{mBq} \mathrm{m}^{-3}$; McNeary and Baskaran, 2003). China is the largest coal producer and consumer in the world. During coal combustion, ${ }^{210} \mathrm{~Pb}$ can be released as fly ash from a coal-fired power plant (Liu et al., 2015), which in turn increases the ${ }^{210} \mathrm{~Pb}$ concentration in ambient air. On the other hand, Shenzhen city is a highradiation background region in China; the soil gas radon concentration was nearly seven times the country's average (Wang et al., 2006; Liu et al., 2015), which may have contributed to a high ${ }^{210} \mathrm{~Pb}$ concentration in this region.

Fig. 2 shows the monthly ${ }^{7} \mathrm{Be}$ and ${ }^{210} \mathrm{~Pb}$ activity concentrations and precipitation in the study period. As shown in the figure, the activity concentrations of both ${ }^{7} \mathrm{Be}$ and ${ }^{210} \mathrm{~Pb}$ showed seasonal variation; they were high in winter and low in summer, similar to those reported in Kumamoto, Japan (Momoshima et al., 2006), and Qingdao, China (Yang et al., 2013). Shenzhen is located in subtropical monsoon regions, which is wet and hot in summer and dry and cool in winter. During the rainy season, precipitation scavenging causes the aerosol concentration to decrease, thus reducing the attachment medium for ${ }^{7} \mathrm{Be}$ and ${ }^{210} \mathrm{~Pb}$ in the air (Yang et al., 2013). On the other hand, maritime air masses that come from the Pacific Ocean usually contain less ${ }^{7} \mathrm{Be}$ and ${ }^{210} \mathrm{~Pb}$, which may also be responsible for the low ${ }^{7} \mathrm{Be}$ and ${ }^{210} \mathrm{~Pb}$ in summer. During the dry winter season, the northeast monsoon that originates from Mongolia and southeastern Siberia carries continental air masses to South China; the long-range-transported ${ }^{210} \mathrm{~Pb}$ from North China may have led to the increased ${ }^{210} \mathrm{~Pb}$ concentration in winter. The production rate of ${ }^{7} \mathrm{Be}$ is latitude dependent, and high ${ }^{7} \mathrm{Be}$ concentrations in aerosols have been reported in northern China (Yang et al., 2013; Gai et al., 2015). The air masses coming from these mid-latitude regions (enriched in ${ }^{7} \mathrm{Be}$ ) may have contributed to the high level of ${ }^{7} \mathrm{Be}$ in winter 


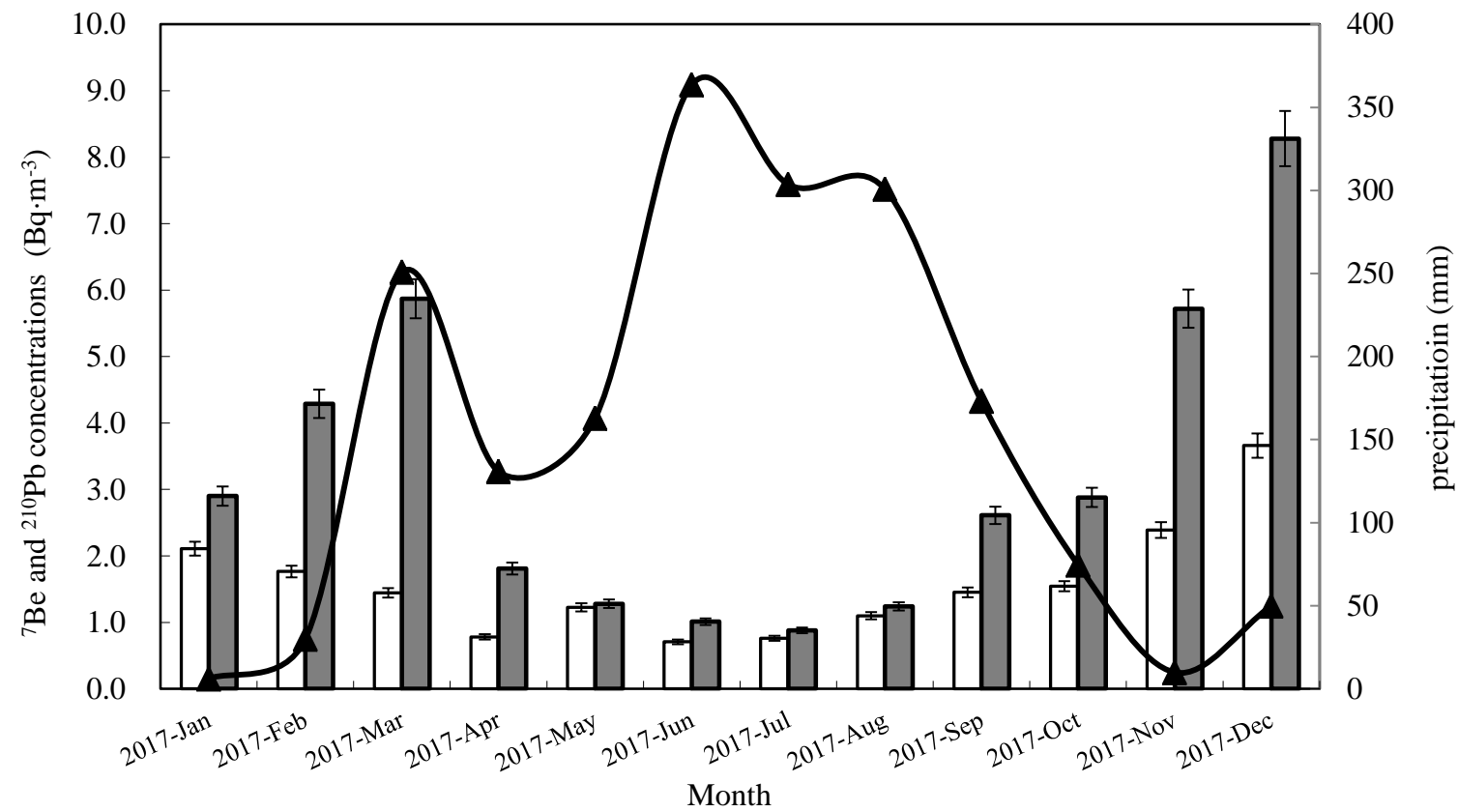

Fig. 2. Seasonal variations of ${ }^{7} \mathrm{Be}$ and ${ }^{210} \mathrm{~Pb}$ concentrations in the air and precipitation.

when northeast monsoon prevailing. Many studies have indicated that at mid-latitude regions, an enhanced air exchange occurs between the stratosphere and troposphere in spring (Pan et al., 2011); stratospheric air intrusion may have brought large amounts of ${ }^{7} \mathrm{Be}$ in March in this region.

\section{Deposition Fluxes of ${ }^{7} \mathrm{Be}$ and ${ }^{210} \mathrm{~Pb}$}

The monthly bulk deposition fluxes of ${ }^{7} \mathrm{Be}$ and ${ }^{210} \mathrm{~Pb}$ along with the precipitation amount are shown in Fig. 3. The deposition fluxes of ${ }^{7} \mathrm{Be}$ and ${ }^{210} \mathrm{~Pb}$ were in the range of 0.25 $3.04 \mathrm{~Bq} \mathrm{~m}^{-2} \mathrm{day}^{-1}$ and $0.34-1.31 \mathrm{~Bq} \mathrm{~m}^{-2} \mathrm{day}^{-1}$, with an annual average of 1.57 and $0.73 \mathrm{~Bq} \mathrm{~m}^{-2}$ day $^{-1}$, respectively. The deposition fluxes of ${ }^{7} \mathrm{Be}$ and ${ }^{210} \mathrm{~Pb}$ showed seasonal variations; high deposition fluxes were observed in spring (March) for ${ }^{7} \mathrm{Be}$ and autumn (August and September) for both ${ }^{7} \mathrm{Be}$ and ${ }^{210} \mathrm{~Pb}$. The study of Mcneary and Baskaran (2003) indicated that the deposition fluxes of ${ }^{7} \mathrm{Be}$ and ${ }^{210} \mathrm{~Pb}$ on the earth's surface are largely influenced by latitude (for ${ }^{7} \mathrm{Be}$ ), longitude (for ${ }^{210} \mathrm{~Pb}$ ), and local meteorological conditions. By comparison, the deposition fluxes of ${ }^{7} \mathrm{Be}$ in Shenzhen fall in the range of those reported in other regions of China (Yi et al., 2007; Du et al., 2008; Zhang et al., 2013; Gai et al., 2015); Cienfuegos in Cuba (Alonso-Hernández et al., 2014); Geneva, Switzerland (Caillet et al., 2001); Spain (Dueñas et al., 2017); and Detroit, USA (McNeary and Baskaran, 2003). Table 1 summarizes the deposition fluxes of ${ }^{7} \mathrm{Be}$ and ${ }^{210} \mathrm{~Pb}$ in 18 stations around the world in the order of latitude. As seen from Table 1, the deposition fluxes of ${ }^{7} \mathrm{Be}$ showed an increasing trend with latitude (from $22.2^{\circ} \mathrm{N}$ to $46.2^{\circ} \mathrm{N}$ ) and were the highest in the mid-latitude regions, reflecting the well-known latitudinal dependence of atmospheric deposition fluxes of ${ }^{7} \mathrm{Be}$, as have been observed in some regions (Du et al., 2015; Gai et al., 2015; Hernandez-Ceballos et al., 2015). However, further studies of bulk deposition of ${ }^{7} \mathrm{Be}$ are still needed, especially in the southern hemisphere regions. For ${ }^{210} \mathrm{~Pb}$, its deposition fluxes at our site were comparable to the global average value $\left(0.53 \mathrm{~Bq} \mathrm{~m}^{-2} \mathrm{day}^{-1}\right)$ for latitude between $20^{\circ} \mathrm{N}$ and $30^{\circ} \mathrm{N}$ (Baskaran, 2011) but lower than those reported in Shanghai, China (1.31 Bq m${ }^{-2}$ day $^{-1}$; Du et al., 2008), and higher than Cienfuegos, Cuba, where a value of $0.13 \mathrm{~Bq} \mathrm{~m}^{-2} \mathrm{day}^{-1}$ was reported (Alonso-Hernández et al., 2014), owing to the significant input of marine air in this place.

Studies have indicated that the atmospheric deposition fluxes of ${ }^{7} \mathrm{Be}$ and ${ }^{210} \mathrm{~Pb}$ are strongly correlated with the rainfall amount (Dueñas et al., 2005; Gai et al., 2015; Dueñas et al., 2017). To study the effect of precipitation on the removal of both nuclides in the air, the deposition fluxes of ${ }^{7} \mathrm{Be}$ and ${ }^{210} \mathrm{~Pb}$ were plotted against the monthly rainfall amount during the sampling period. As shown in Fig. 4, a positive correlation exists between ${ }^{7} \mathrm{Be}$ and ${ }^{210} \mathrm{~Pb}$ deposition fluxes and precipitation ( $r=0.58$ and $r=0.47$, respectively). Furthermore, if we narrow the time scale from August to December instead of the entire year, the coefficients between rainfall and fluxes were 0.98 for ${ }^{7} \mathrm{Be}$ and 0.95 for ${ }^{210} \mathrm{~Pb}$. It is suggested that the removal processes of these two radionuclides from the air are similar, and rainfall is the dominant factor for the scavenging of ${ }^{7} \mathrm{Be}$ and ${ }^{210} \mathrm{~Pb}$ in autumn and early winter. In general, the correlation coefficients between precipitation and deposition fluxes of ${ }^{7} \mathrm{Be}$ were higher than that of ${ }^{210} \mathrm{~Pb}$. Moreover, similar results have been observed by other authors at various stations, such as Xiamen (Yi et al., 2007) and Shanghai (Du et al., 2008) in China; Malaga, Spain (Dueñas et al., 2005); Cienfuegos, Cuba (AlonsoHernández et al., 2014); and Detroit, USA (McNeary and Baskaran, 2003). This may be due to their distinct source; ${ }^{7} \mathrm{Be}$ is a cosmogenic radionuclide, whereas ${ }^{210} \mathrm{~Pb}$ is mainly derived through the decay of ${ }^{222} \mathrm{Rn}$ from soil. The inventories of ${ }^{210} \mathrm{~Pb}$ in the top soil layer are higher than that of ${ }^{7} \mathrm{Be}$ and are susceptible to the re-suspension process; thus, the dry fallout of ${ }^{210} \mathrm{~Pb}$ is expected to be much higher and is less 


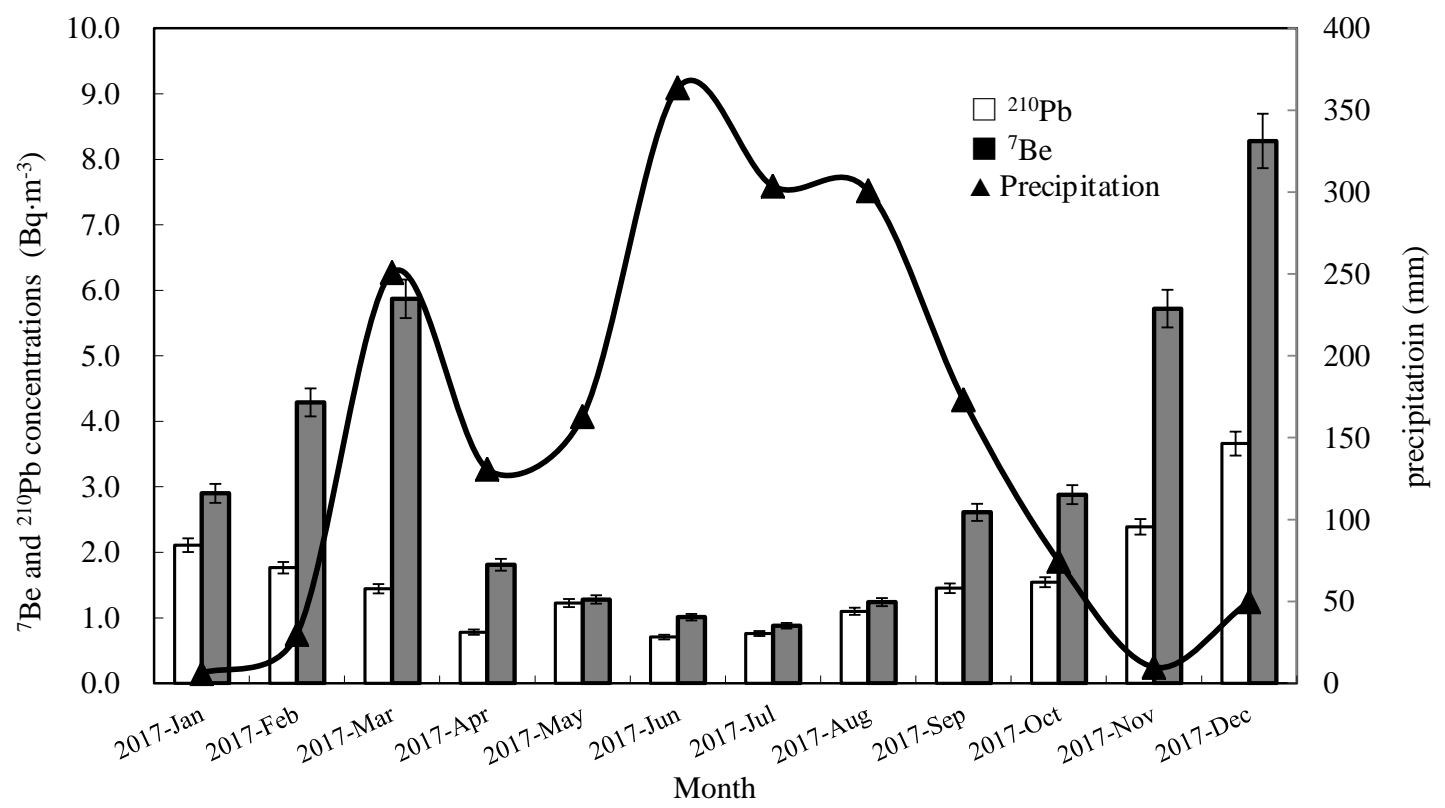

Fig. 3. Monthly deposition fluxes of ${ }^{7} \mathrm{Be}$ and ${ }^{210} \mathrm{~Pb}$, and precipitation.

Table 1. Deposition fluxes of ${ }^{7} \mathrm{Be}$ and ${ }^{210} \mathrm{~Pb}$ in different regions.

\begin{tabular}{|c|c|c|c|c|c|}
\hline Location & Coordinates & Collection time & $\begin{array}{l}{ }^{7} \mathrm{Be} \text { fluxes } \\
\mathrm{Bq} \mathrm{m}^{-2} \text { day }^{-1}\end{array}$ & $\begin{array}{l}{ }^{210} \mathrm{~Pb} \text { fluxes } \\
\mathrm{Bq} \mathrm{m}^{-2} \text { day }^{-1}\end{array}$ & Reference \\
\hline Cienfuegos, Cuba & $22^{\circ} \mathrm{N}, 80.3^{\circ} \mathrm{W}$ & $2010.2-2011.1$ & 1.89 & 0.13 & $\begin{array}{l}\text { Alonso-Hernández et al., } \\
2014\end{array}$ \\
\hline Shenzhen, China & $22.5^{\circ} \mathrm{N}, 113.9^{\circ} \mathrm{E}$ & 2017.1-2017.12 & 1.57 & 0.73 & This study \\
\hline Guangzhou, China & $23.2^{\circ} \mathrm{N}, 113.3^{\circ} \mathrm{E}$ & $2012.7-2013.6$ & 1.32 & - & Gai et al., 2015 \\
\hline Xiamen, China & $24.3^{\circ} \mathrm{N}, 118.5^{\circ} \mathrm{E}$ & 2004.3-2005.4 & 1.64 & 0.51 & Yi et al., 2007 \\
\hline Shanghai, China & $31.1^{\circ} \mathrm{N}, 121.2^{\circ} \mathrm{E}$ & $2005.11-2006.10$ & 5.68 & 1.31 & Du et al., 2008 \\
\hline Nagasaki, Japan & $32.5^{\circ} \mathrm{N}, 129.5^{\circ} \mathrm{E}$ & $2001.1-2001.11$ & 4.04 & 0.64 & Hirose et al., 2004 \\
\hline Qingdao, China & $35.8^{\circ} \mathrm{N}, 120.5^{\circ} \mathrm{E}$ & $2012.8-2013.7$ & 2.45 & - & Gai et al., 2015 \\
\hline Tsukuba, Japan & $36^{\circ} \mathrm{N}, 140^{\circ} \mathrm{E}$ & 2001.1-2001.11 & 3.63 & 0.48 & Hirose et al., 2004 \\
\hline Málaga, Spain & $36.7^{\circ} \mathrm{N}, 4.5^{\circ} \mathrm{W}$ & 2005-2015 & 3.30 & 0.39 & Dueñas et al., 2017 \\
\hline Norfolk, USA & $36.9^{\circ} \mathrm{N}, 76.3^{\circ} \mathrm{W}$ & $1983.1-1984.12$ & 5.89 & 0.38 & Olsen et al., 1985 \\
\hline Ansan, Korea & $37.2^{\circ} \mathrm{N}, 126.5^{\circ} \mathrm{E}$ & $1992-1993$ & 4.67 & - & Kim et al., 1998 \\
\hline Stillpond, USA & $39^{\circ} \mathrm{N}, 76.1^{\circ} \mathrm{W}$ & 1995.9-1996.8 & 5.94 & 0.36 & Kim et al., 2000 \\
\hline Beijing, China & $39.5^{\circ} \mathrm{N}, 116.4^{\circ} \mathrm{E}$ & 2012.7-2013.6 & 3.91 & - & Gai et al., 2015 \\
\hline New York, USA & $40.9^{\circ} \mathrm{N}, 73.1 \mathrm{~W}$ & 2008.4-2009.12 & 8.52 & 0.40 & Renfro et al., 2013 \\
\hline Boston, USA & $42.3^{\circ} \mathrm{N}, 71^{\circ} \mathrm{W}$ & $2000.9-2007.8$ & 7.10 & - & Zhu and Olsen, 2009 \\
\hline Detroit, USA & $42.3^{\circ} \mathrm{N}, 83.1^{\circ} \mathrm{W}$ & 1999.9-2001.3 & 5.20 & 0.64 & $\begin{array}{l}\text { McNeary and Baskaran, } \\
2003\end{array}$ \\
\hline Bordeaux, France & $45^{\circ} \mathrm{N}, 0.4^{\circ} \mathrm{W}$ & 2006.1-2007.1 & 3.44 & 0.28 & Sarri et al., 2010 \\
\hline Geneva, Switzerland & $46.2^{\circ} \mathrm{N}, 6.1^{\circ} \mathrm{E}$ & $1997.11-1998.11$ & 5.72 & 0.41 & Caillet et al., 2001 \\
\hline
\end{tabular}

controlled by precipitation compared with ${ }^{7} \mathrm{Be}$. Although the deposition fluxes of ${ }^{7} \mathrm{Be}$ are mainly controlled by precipitation, its fallout has a certain limit, regardless of the rainfall amount. As shown in Fig. 3, the deposition fluxes of ${ }^{7} \mathrm{Be}$ remained relatively constant from April to July, with which rainfall fluctuated greatly; the maximum monthly precipitation occurred in June $(363.6 \mathrm{~mm})$, but the highest deposition fluxes of ${ }^{7} \mathrm{Be}$ were observed in March. Gai et al. (2015) observed a negative correlation between the annual deposition fluxes of ${ }^{7} \mathrm{Be}$ and the average annual precipitation at different latitudes; thus, it is indicated that the fallout of ${ }^{7} \mathrm{Be}$ in certain latitude does not increase with continuing rainfall due to its latitude dependence.

Wet precipitation, dry deposition, atmospheric circulation, continental or oceanic air masses are considered main factors that influence the deposition fluxes of ${ }^{7} \mathrm{Be}$ and ${ }^{210} \mathrm{~Pb}$. Dry deposition is estimated to contribute to $14 \%$ of the global ${ }^{210} \mathrm{~Pb}$ fallout (Balkanski et al., 1993), but it could be much higher in semi-arid areas and even more important than wet fallout (Rastogi and Sarin, 2008). As shown in Figs. 2 and 3 , the monthly rainfall was low in January and February, whereas the deposition fluxes of ${ }^{7} \mathrm{Be}$ and ${ }^{210} \mathrm{~Pb}$ were still 


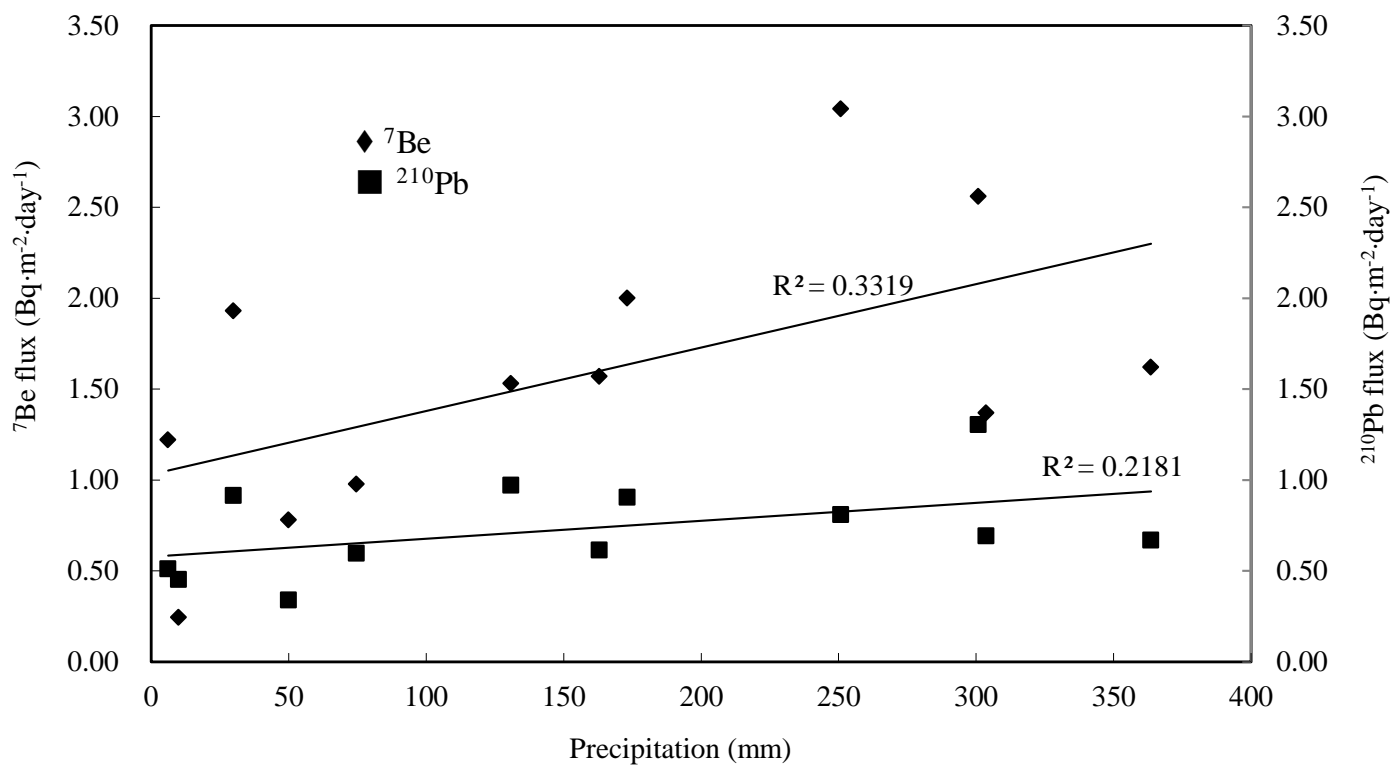

Fig. 4. Correlation between deposition fluxes of ${ }^{7} \mathrm{Be}$ and ${ }^{210} \mathrm{~Pb}$, and precipitation.

relatively high, along with high concentrations of ${ }^{7} \mathrm{Be}$ and ${ }^{210} \mathrm{~Pb}$ in the air. It is suggested that dry deposition may play an important role in winter months in this region. In addition to dry and wet deposition, the deposition fluxes of ${ }^{7} \mathrm{Be}$ and ${ }^{210} \mathrm{~Pb}$ are also affected by the origin and pathway of air masses as well as atmospheric circulation. During fall when northeast monsoon prevailing, the continental air masses (rich in ${ }^{7} \mathrm{Be}$ and ${ }^{210} \mathrm{~Pb}$ ) could have led to high deposition fluxes of ${ }^{7} \mathrm{Be}$ and ${ }^{210} \mathrm{~Pb}$ in August and September, with plenty of precipitation during these periods. In Shanghai, China, high deposition fluxes of ${ }^{210} \mathrm{~Pb}$ were ascribed to storm dust from northern and northwestern China (Du et al., 2008), reflecting the influence of air masses on local ${ }^{210} \mathrm{~Pb}$ deposition. During spring, as the mid-latitude troposphere narrows, the enhanced air exchange between the stratosphere and troposphere may have caused the high deposition fluxes of ${ }^{7} \mathrm{Be}$ in March.

Total Deposition Velocity of Aerosols Using ${ }^{7} \mathrm{Be}$ and ${ }^{210} \mathrm{~Pb}$

Atmospheric deposition is one of the key processes that remove pollutants from air and is considered the major source of nutrients and toxic substances to ecosystems. The deposition velocity of aerosol particles can be used to estimate the deposition fluxes of air pollutants and to assess environmental impact. The total deposition velocity $\left(V_{\mathrm{d}}\right)$ of any radionuclide in air can be determined as follows (McNeary et al., 2003; Dueñas et al., 2005):

$V_{d}=\frac{F}{C}$

where $F$ and $C$ are the total deposition flux (wet + dry) and the activity concentration of this radionuclide in aerosols, respectively. In this study, the total deposition velocity of ${ }^{7} \mathrm{Be}$ and ${ }^{210} \mathrm{~Pb}$ were calculated as the ratio of the deposition fluxes of ${ }^{7} \mathrm{Be}$ and ${ }^{210} \mathrm{~Pb}$ to the monthly average concentrations of ${ }^{7} \mathrm{Be}$ and ${ }^{210} \mathrm{~Pb}$ in the air.

${ }^{7} \mathrm{Be}$ and ${ }^{210} \mathrm{~Pb}$ serve as good tracers for studying the total deposition velocity of aerosols (McNeary et al., 2003). First, the activity concentrations and deposition fluxes of ${ }^{7} \mathrm{Be}$ and ${ }^{210} \mathrm{~Pb}$ in ambient air can be easily determined. Second, the production rates of ${ }^{7} \mathrm{Be}$ and ${ }^{210} \mathrm{~Pb}$ at any given site remain constant over a long period. Third, the size distributions of ${ }^{7} \mathrm{Be}$ and ${ }^{210} \mathrm{~Pb}$ in aerosols are similar to other atmospheric particulate pollutants; thus, the deposition velocity of ${ }^{7} \mathrm{Be}$ and ${ }^{210} \mathrm{~Pb}$ can be used to determine the deposition fluxes of these pollutants to the earth's surface.

Table 2 presents the monthly average deposition velocity of ${ }^{7} \mathrm{Be}$ and ${ }^{210} \mathrm{~Pb}$, together with the precipitation amount, the number of rainy days, and atmospheric fine particulate matter $\left(\mathrm{PM}_{2.5}\right)$ during the sampling period. The total deposition velocity of ${ }^{7} \mathrm{Be}$ at our site ranged from 0.04 to $2.06 \mathrm{~cm} \mathrm{~s}^{-1}$, with an average value of $0.83 \mathrm{~cm} \mathrm{~s}^{-1}$. The corresponding values for ${ }^{210} \mathrm{~Pb}$ varied from 0.09 to $1.24 \mathrm{~cm} \mathrm{~s}^{-1}$, with an average value of $0.62 \mathrm{~cm} \mathrm{~s}^{-1}$. Moreover, both ${ }^{7} \mathrm{Be}$ and ${ }^{210} \mathrm{~Pb}$ deposition velocity displayed seasonal variations, and they were high in summer and low in winter. Limited data are available on the simultaneously measured deposition velocity for ${ }^{7} \mathrm{Be}$ and ${ }^{210} \mathrm{~Pb}$. Table 3 lists the deposition velocity of ${ }^{7} \mathrm{Be}$ and ${ }^{210} \mathrm{~Pb}$ calculated in previous studies. The deposition velocity of ${ }^{7} \mathrm{Be}$ and ${ }^{210} \mathrm{~Pb}$ at our site were similar to those reported in Detroit, Michigan (McNeary et al., 2003), and Norfolk, Virginia (Todd et al., 1989). The deposition velocity of ${ }^{7} \mathrm{Be}$ was higher than that of ${ }^{210} \mathrm{~Pb}$, except in a study from Málaga, Spain (Dueñas et al., 2005). Considering ${ }^{210} \mathrm{~Pb}$ is mainly derived from the decay of ${ }^{222} \mathrm{Rn}$, the activity concentration of ${ }^{210} \mathrm{~Pb}$ in aerosol near the ground is expected to be high; thus, the total deposition velocity of ${ }^{210} \mathrm{~Pb}$ is expected to be low (McNeary et al., 2003). The strong positive correlation $\left(\mathrm{r}=0.80\right.$; Fig. 5) between ${ }^{7} \mathrm{Be}$ and ${ }^{210} \mathrm{~Pb}$ deposition velocity indicates that, irrespective of the different source, both radiotracers are attached to similar size aerosols and they are removed from the atmosphere by similar mechanisms. 
Table 2. Deposition velocity of ${ }^{7} \mathrm{Be}$ and ${ }^{210} \mathrm{~Pb}$ together with precipitation amount, rainy days, and $\mathrm{PM}_{2.5}$ concentrations in the air.

\begin{tabular}{llllll}
\hline Month & $\begin{array}{l}{ }^{7} \text { Be velocity } \\
\left(\mathrm{cm} \mathrm{s}^{-1}\right)\end{array}$ & $\begin{array}{l}{ }^{210} \mathrm{~Pb} \text { velocity } \\
\left(\mathrm{cm} \mathrm{s}^{-1}\right)\end{array}$ & $\begin{array}{l}\text { Precipitation } \\
(\mathrm{mm})\end{array}$ & $\begin{array}{l}\text { Rainfall days } \\
(\text { days })\end{array}$ & $\begin{array}{l}\mathrm{PM}_{2.5} \\
\left(\mu \mathrm{g} \mathrm{m}^{-3}\right)\end{array}$ \\
\hline Jan & 0.42 & 0.24 & 6.1 & 10 & 36.9 \\
Feb & 0.45 & 0.52 & 29.9 & 8 & 34.8 \\
Mar & 0.52 & 0.56 & 250.8 & 9 & 29.8 \\
Apr & 0.85 & 1.24 & 130.8 & 11 & 26.2 \\
May & 1.23 & 0.50 & 163.0 & 10 & 25.9 \\
Jun & 1.60 & 0.95 & 363.6 & 21 & 11.4 \\
Jul & 1.56 & 0.91 & 303.6 & 16 & 12.9 \\
Aug & 2.06 & 1.19 & 300.8 & 17 & 16.6 \\
Sep & 0.77 & 0.62 & 173.1 & 13 & 24.2 \\
Oct & 0.34 & 0.39 & 74.6 & 7 & 29.5 \\
Nov & 0.04 & 0.19 & 9.9 & 3 & 35.9 \\
Dec & 0.09 & 0.09 & 49.9 & 4 & 36.2 \\
\hline
\end{tabular}

Table 3. Deposition velocity of aerosols in different locations using ${ }^{7} \mathrm{Be}$ and ${ }^{210} \mathrm{~Pb}$.

\begin{tabular}{llllll}
\hline Location & Coordinates & Collection time & ${ }^{7} \mathrm{Be}\left(\mathrm{cm} \mathrm{s}^{-1}\right)$ & ${ }^{210} \mathrm{~Pb}\left(\mathrm{~cm} \mathrm{~s}^{-1}\right)$ & Reference \\
\hline Bermuda & $33^{\circ} \mathrm{N}, 64^{\circ} \mathrm{W}$ & $1979.5-1979.6$ & 4.0 & 1.0 & Turekian et al., 1983 \\
New Haven, Connecticut & $41^{\circ} \mathrm{N}, 73^{\circ} \mathrm{W}$ & $1977.2-1978$ & 2.8 & 0.95 & Turekian et al., 1983 \\
Quillayute, Washington & $47^{\circ} \mathrm{N}, 124^{\circ} \mathrm{W}$ & $1976-1977$ & 1.0 & - & Crecelius, 1981 \\
Norfolk, Virginia & $35^{\circ} \mathrm{N}, 84^{\circ} \mathrm{W}$ & $1983-1984$ & 1.3 & 0.7 & Todd et al., 1989 \\
Neuherberg, Germany & $48^{\circ} \mathrm{N}, 1^{\circ} \mathrm{E}$ & $1981-1999$ & - & $0.7-1.7(1.0)$ & Winkler and Rosner, \\
& & & & & 2000 \\
Detroit, Michigan & $42^{\circ} \mathrm{N}, 83^{\circ} \mathrm{W}$ & $1999.9-2001.02$ & $0.17-6.05(1.6)$ & $0.04-3.64(1.1)$ & $\begin{array}{l}\text { McNeary and Baskaran, } \\
\text { Malaga, Spain }\end{array}$ \\
& $36^{\circ} \mathrm{N}, 4^{\circ} \mathrm{W}$ & $1992.1-1999.12$ & $0.07-1.2(0.4)$ & $0.2-4.3(1.5)$ & Dueñas et al., 2005 \\
Shenzhen, China & $23^{\circ} \mathrm{N}, 113^{\circ} \mathrm{E}$ & $2017.1-2017.12$ & $0.05-2.4(0.96)$ & $0.22-1.44(0.78)$ & This study \\
\hline
\end{tabular}

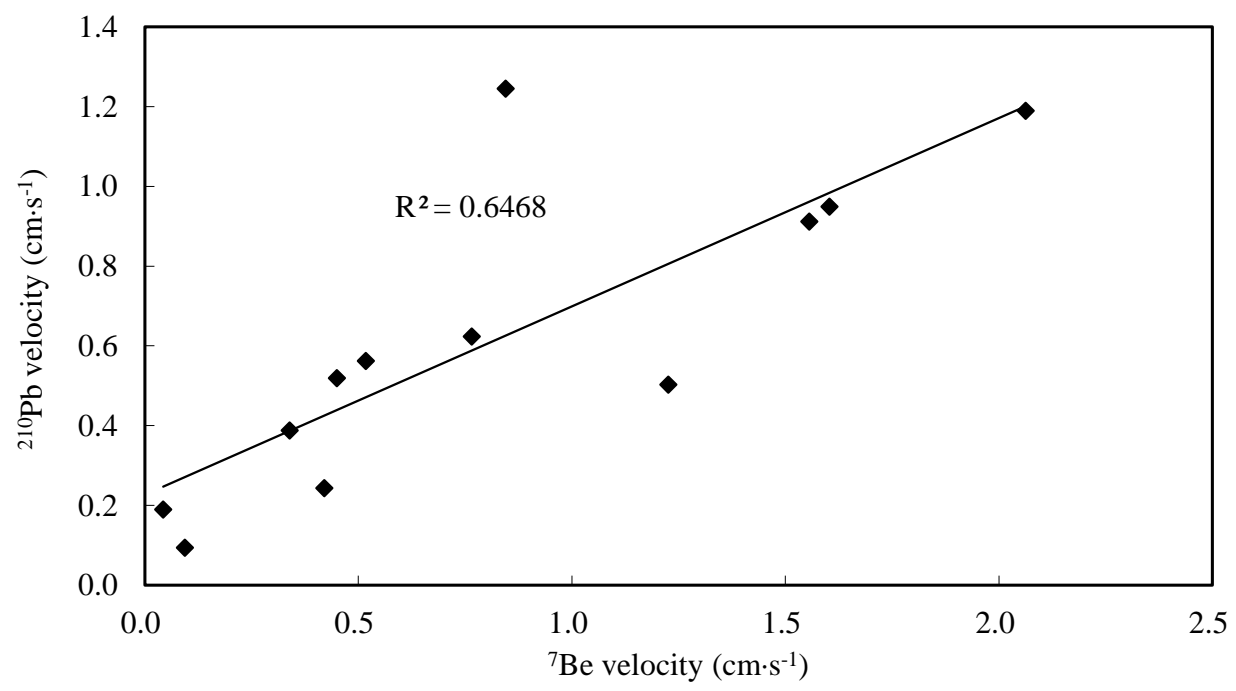

Fig. 5. Deposition velocity of ${ }^{7} \mathrm{Be}$ versus ${ }^{210} \mathrm{~Pb}$.

The deposition velocity of atmospheric aerosols depends on the particle size and meteorological conditions. ${ }^{7} \mathrm{Be}$ and ${ }^{210} \mathrm{~Pb}$ in air are mainly attached to fine particles, and the most likely route for their removal is rainout. For a better understanding of the rainout effect, the deposition velocity of ${ }^{7} \mathrm{Be}$ and ${ }^{210} \mathrm{~Pb}$ versus precipitation and the number of rainy days are plotted in Fig. 6. As seen in the figure, both ${ }^{7} \mathrm{Be}$ and ${ }^{210} \mathrm{~Pb}$ deposition velocity showed a significant positive correlation with the rainfall amount and the number of rainy days. It is suggested that precipitation is the key factor in affecting the deposition velocity of ${ }^{7} \mathrm{Be}$ and ${ }^{210} \mathrm{~Pb}$ and plays a crucial role in removing these radionuclides from air. The deposition velocity of radionuclide is a function of its deposition fluxes and the activity concentration in air. 

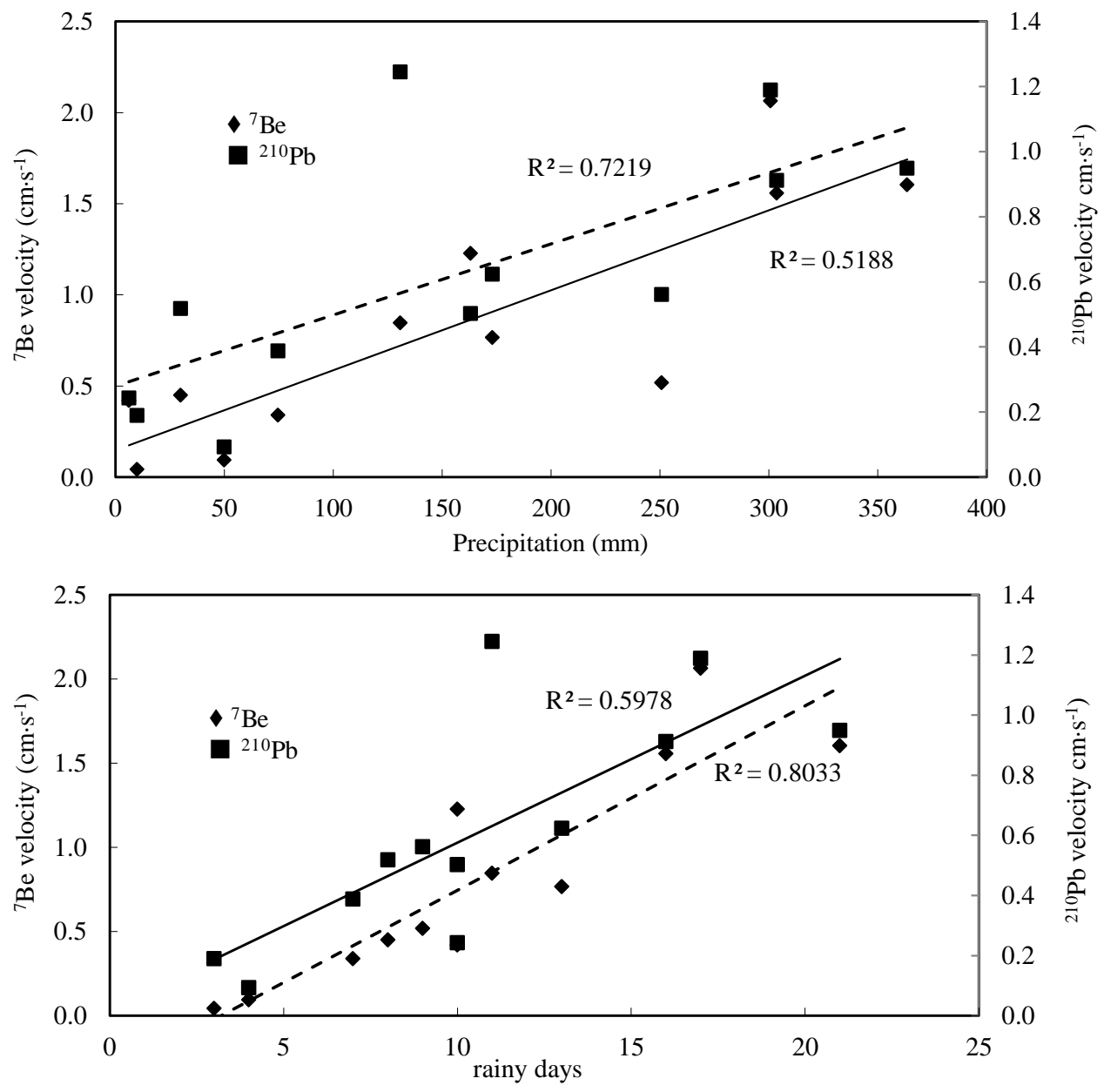

Fig. 6. Deposition velocity of ${ }^{7} \mathrm{Be}$ and ${ }^{210} \mathrm{~Pb}$ in correlation with precipitation and the number of rainy days.

Atmospheric fine particulate matter, the transfer medium of particle-active radionuclides, is an important factor in controlling the activity concentration of radionuclides in air, which in turn affect their deposition velocity. As seen in Fig. 7, strong negative correlations were observed between ${ }^{7} \mathrm{Be}(\mathrm{r}=-0.91)$ and ${ }^{210} \mathrm{~Pb}(\mathrm{r}=-0.78)$ deposition velocity, and $\mathrm{PM}_{2.5}$ content in the air. Similar results were reported in Dueñas et al. (2005) and McNeary and Baskaran (2003), with negative correlations observed between the two deposition velocity and total suspended particle (TSP), and weak correlations between ${ }^{7} \mathrm{Be}$ and ${ }^{210} \mathrm{~Pb}$ deposition velocity and the particulate matter collected on the filter membranes. Shenzhen features a subtropical monsoon climate; the summer monsoon occurs annually, and typhoons are common in this region. During the rainy season, the lower layer of the atmosphere is rapidly washed and the deposition velocity of ${ }^{7} \mathrm{Be}$ and ${ }^{210} \mathrm{~Pb}$ are expected to be high; as seen from Table 2 , the deposition velocity of ${ }^{7} \mathrm{Be}$ or ${ }^{210} \mathrm{~Pb}$ displayed the highest values in summer, with an average of 1.74 and $1.02 \mathrm{~cm} \mathrm{~s}^{-1}$, respectively. During the dry winter season, $\mathrm{PM}_{2.5}$ concentrations in air were high $\left(>30 \mu \mathrm{g} \mathrm{m}^{-3}\right)$. Considering that ${ }^{7} \mathrm{Be}$ and ${ }^{210} \mathrm{~Pb}$ are mainly attached to fine particles $(<1 \mu \mathrm{m})$ and are feebly affected by gravitational settling, the dry fallout of ${ }^{7} \mathrm{Be}$ or ${ }^{210} \mathrm{~Pb}$ is expected to be low, which results in the low deposition velocity of these radionuclides in winter.

\section{CONCLUSION}

The atmospheric activity concentrations and bulk deposition fluxes of ${ }^{7} \mathrm{Be}$ and ${ }^{210} \mathrm{~Pb}$ were simultaneously measured for a whole year in Shenzhen, South China. Owing to the elevated ${ }^{222} \mathrm{Rn}$ level in this region's soil, relatively high ${ }^{210} \mathrm{~Pb}$ concentrations in the atmospheric aerosols were observed. The activity of both airborne ${ }^{7} \mathrm{Be}$ and ${ }^{210} \mathrm{~Pb}$ and the bulk deposition fluxes showed seasonal variations, with higher winter values and lower summer ones. Precipitation and the origin and pathway of air masses, in addition to atmospheric circulation, are considered the primary controlling factors for ${ }^{7} \mathrm{Be}$ and ${ }^{210} \mathrm{~Pb}$ 's activity concentrations in the air and their deposition fluxes in the studied region. Using these two radiotracers to calculate the deposition velocity of aerosols, we discovered that the deposition velocities of ${ }^{7} \mathrm{Be}$ and ${ }^{210} \mathrm{~Pb}$ were strongly positively correlated with the rainfall amount but negatively correlated with the airborne $\mathrm{PM}_{2.5}$ concentration. Precipitation plays a critical role in removing these radionuclides from the air, and the deposition velocities were high during the summer and low during the winter due to the activity distributions of ${ }^{7} \mathrm{Be}$ and ${ }^{210} \mathrm{~Pb}$ and the meteorological conditions in this region. 


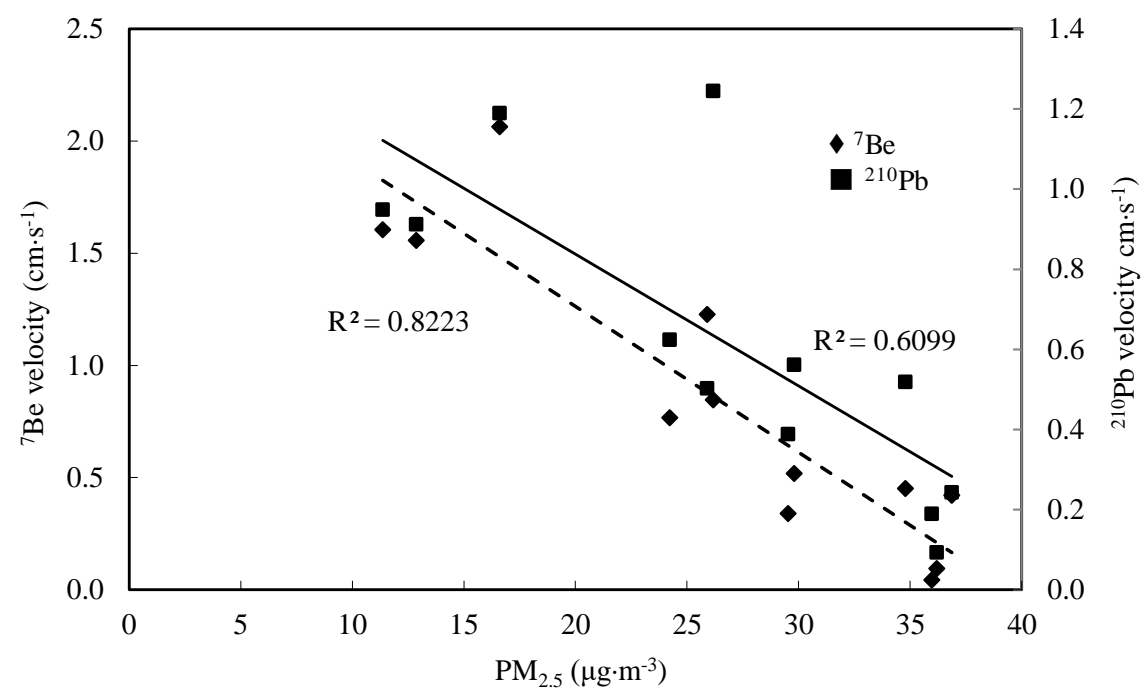

Fig. 7. Deposition velocity of ${ }^{7} \mathrm{Be}$ and ${ }^{210} \mathrm{~Pb}$ in correlation with $\mathrm{PM}_{2.5}$ in the air.

\section{ACKNOWLEDGMENTS}

This work was supported by Shenzhen Science and Technology Innovation Project (No. JCYJ20170818100556755), the Natural Science Foundation of Guangdong Province (No. 2016A030313037), and the National Natural Science Foundation of China (No. $11275130,41102217)$. We would like to thank the reviewers for their valuable suggestions to improve the manuscript.

\section{SUPPLEMENTARY MATERIAL}

Supplementary data associated with this article can be found in the online version at http://www.aaqr.org.

\section{REFERENCES}

Ahmed, A.A., Mohamed, A., Ali, A.E., Barakat, A., Abd ElHady, M. and El-Hussein, A. (2004). Seasonal variations of aerosol residence time in the lower atmospheric boundary layer. J. Environ. Radioact. 77: 275-283. https://doi.org/10.1016/j.jenvrad.2004.03.011

Ali, N., Khan, E.U., Akhter, P., Rana, M.A., Rajput, M.U., Khattak, N.U., Malik, F. and Hussain, S. (2011). Wet depositional fluxes of ${ }^{210} \mathrm{~Pb}$ - and ${ }^{7} \mathrm{Be}$-bearing aerosols at two different altitude cities of North Pakistan. Atmos. Environ. 45: 5699-5709. https://doi.org/10.1016/j.atmos env.2011.07.032

Alonso-Hernández, C.M., Morera-Gómez, Y., CartaswÁguila, H. and Guillén-Arruebarrena, A. (2014). Atmospheric deposition patterns of ${ }^{210} \mathrm{~Pb}$ and ${ }^{7} \mathrm{Be}$ in Cienfuegos, Cuba. J. Environ. Radioact. 138: 149-155. https://doi.org/10.10 16/j.jenvrad.2014.08.023

Balkanski, Y.J., Jacon, D.J., Gardner, G.M., Graustein, W.C., and Turekian, K.K. (1993). Transport and residence times of tropospheric aerosols inferred from a global three-dimensional simulation of ${ }^{210} \mathrm{~Pb}$. J. Geophys. Res. 98: 20573-20586. https://doi.org/10.1029/93JD02456

Baskaran, M., Coleman, C.H. and Santschi, P.H. (1993).
Atmospheric depositional fluxes of ${ }^{7} \mathrm{Be}$ and ${ }^{210} \mathrm{~Pb}$ at Galveston and College Station, Texas. J. Geophys. Res. 98: 20555-20571. https://doi.org/10.1029/93JD02182

Baskaran, M. (2011). Po-210 and Pb-210 as atmospheric tracers and global Pb-210 fallout: A review. J. Environ. Radioact. 102: 500-513. https://doi.org/10.1016/j.jenvrad. 2010.10.007

Caillet, S., Arpagaus, P., Monna, F. and Dominik, J. (2001). Factors controlling ${ }^{7} \mathrm{Be}$ and ${ }^{210} \mathrm{~Pb}$ atmospheric deposition as revealed by sampling individual rain events in the region of Geneva, Switzerland. J. Environ. Radioact. 53: 241256. https://doi.org/10.1016/S0265-931X(00)00130-2

Chameides, W.L., Yu, H., Liu, S.C., Bergin, M., Zhou, X., Mearns, L., Wang, G., Kiang, C.S., Saylor, R.D., Luo, C., Huang, Y., Steiner, A. and Giorgi, F. (1999). Case study of the effects of atmospheric aerosols and regional haze on agriculture: An opportunity to enhance crop yields in China through emission controls? PNAS 96: 1362613633. https://doi.org/10.1073/pnas.96.24.13626

Chham, E., Piñero-García, F., González-Rodelas, P. and Ferro-García, M.A. (2017). Impact of air masses on the distribution of ${ }^{210} \mathrm{~Pb}$ in the southeast of Iberian Peninsula air. J. Environ. Radioact. 177: 169-183. https://doi.org/10. 1016/j.jenvrad.2017.06.030

Crecelius, E.A. (1981). Prediction of marine atmospheric deposition rates using total ${ }^{7} \mathrm{Be}$ deposition velocities. Atmos. Environ. 5: 579-582. https://doi.org/10.1016/000 4-6981(81)90188-8

Du, J., Zhang, J., Jing, Z. and Wu, Y. (2008). Deposition patterns of atmospheric ${ }^{7} \mathrm{Be}$ and ${ }^{210} \mathrm{~Pb}$ in coast of East China Sea, Shanghai, China. Atmos. Environ. 42: 51015109. https://doi.org/10.1016/j.atmosenv.2008.02.007

Du, J., Du, J., Baskaran, M., Bi, Q., Huang, D. and Jiang, Y. (2015). Temporal variations of atmospheric depositional fluxes of ${ }^{7} \mathrm{Be}$ and ${ }^{210} \mathrm{~Pb}$ over 8 years $(2006-2013)$ at Shanghai, China, and synthesis of global fallout data. $J$. Geophy. Res. 120: 4323-4339. https://doi.org/10.1002/20 14JD022807

Dueñas, C., Fernandez, M.C., Carretero, J., Liger, E. and 
Cañete, S. (2005). Deposition velocities and washout ratios on a coastal site calculated from ${ }^{7} \mathrm{Be}$ and ${ }^{210} \mathrm{~Pb}$ measurements. Atmos. Environ. 39: 6897-6908. https://doi.org/10.1016/j.atmosenv.2005.08.008

Dueñas, C., Fernandez, M.C., Carretero, J., Liger, E. and Cañete, S. (2011b). Atmospheric deposition of ${ }^{7} \mathrm{Be}$ at a coastal Mediterranean station. J. Geophysical. Res. 106: 34059-34065. https://doi.org/10.1029/2001JD000771

Dueñas, C., Orza, J.A.G., Cabello, M., Fernández, M.C., Cañete, S., Pérez, M. and Gordo, E. (2011b). Air mass origin and its influence on radionuclide activities $\left({ }^{7} \mathrm{Be}\right.$ and ${ }^{210} \mathrm{~Pb}$ ) in aerosol particles at a coastal site in the western Mediterranean. Atmos. Res. 101: 205-214. https://doi.org/ 10.1016/j.atmosres.2011.02.011

Dueñas, C., Gordo, E., Liger, E., Cabello, M., Cañete, S., Pérez, M. and de la Torre-Luque, P. (2017). ${ }^{7} \mathrm{Be},{ }^{210} \mathrm{~Pb}$ and ${ }^{40} \mathrm{~K}$ depositions over 11 years in Málaga. J. Environ. Radioact. 178-179: 325-334. https://doi.org/10.1016/j.je nvrad.2017.09.010

Feely, H.W., Larsen, R.J. and Sanderson, C.G. (1989). Factors that cause seasonal variations in beryllium-7 concentrations in surface air. J. Environ. Radioact. 9: 223-249. https://doi.org/10.1016/0265-931X(89)90046-5

Gai, N., Pan, J., Yin, X.C., Zhu, X.H., Yu, H.Q., Li, Y., Tan, K.Y., Jiao, X.C. and Yang, Y.L. (2015). Latitudinal distributions of activities in atmospheric aerosols, deposition fluxes, and soil inventories of ${ }^{7} \mathrm{Be}$ in the East Asian monsoon zone. J. Environ. Radioact. 148: 59-66. https://doi.org/10.1016/j.jenvrad.2015.06.011

Grossi, C., Bellester, J., Serrano, I., Galmarini, S., Camacho, A., Curcoll, R., Morguí, J.A., Rodò, X. and Duch, M.A. (2016). Influence of long-range atmospheric transport pathways and climate teleconnection patterns on the variability of surface ${ }^{210} \mathrm{~Pb}$ and ${ }^{7} \mathrm{Be}$ concentrations in southwestern Europe. J. Environ. Radioact. 165: 103114. https://doi.org/10.1016/j.jenvrad.2016.09.011

Hernandez-Ceballos, M.A., Cinelli, G., Marín Ferrer, M., Tollefsen, T., De Felice, L., Nweke, E., Tognoli, P.V., Vanzo, S. and De Cort, M. (2015). A climatology of ${ }^{7} \mathrm{Be}$ in surface air in European Union. J. Environ. Radioact. 141: 62-70. https://doi.org/10.1016/j.jenvrad.2014.12.003

Hirose, K., Honda, T., Yagishita, S., Igrarshi, Y. and Aoyama, M. (2004). Deposition behaviors of ${ }^{210} \mathrm{~Pb},{ }^{7} \mathrm{Be}$ and thorium isotopes observed in Tsukuba and Nagasaki, Japan. Atmos. Environ. 38: 6601-6608. https://doi.org/10. 1016/j.atmosenv.2004.08.012

Ioannidou, A., Manolopoulou, M. and Papastefanou, C. (2005). Temporal changes of ${ }^{7} \mathrm{Be}$ and ${ }^{210} \mathrm{~Pb}$ in surface air at temperate latitudes $40^{\circ} \mathrm{N}$. Appl. Radiat. Isot. 63: $277-$ 284. https://doi.org/10.1016/j.apradiso.2005.03.010

Kim, G., Hussain, N., Scudlark, J.R. and Church, T.M. (2000). Factors influencing the atmospheric depositional fluxes of stable $\mathrm{Pb},{ }^{210} \mathrm{~Pb}$ and ${ }^{7} \mathrm{Be}$ into Chesapeake Bay. $J$. Atmos. Chem. 36: 65-79. https://doi.org/10.1023/A:1006 383030362

Kim, S.H., Hong, G.H., Baskaran, M., Par, K.M. and Chang, S.C. (1998). Wet removal of atmospheric ${ }^{7} \mathrm{Be}$ and ${ }^{210} \mathrm{~Pb}$ at the Korean Yellow Sea coast. Yellow Sea 4: 58-68.

Lal, D. and Peters, B. (1967). Cosmic ray produced radioactivity on the earth. In Kosmische Strahlung II / Cosmic Rays II, Sitte, K. (Ed.), Springer Berlin Heidelberg, Berlin, Heidelberg, pp. 551-612.

Lal, D. (1968). The radioactivity of the atmosphere and hydrosphere. Annu. Rev. Nucl. Sci. 18: 407-435. https://doi.org/10.1146/annurev.ns.18.120168.002203

Lee, C.S.L., Li, X., Zhang, G., Peng, X.Z. and Zhang, L. (2005). Biomonitoring of trace metals in the atmosphere using moss (Hypnum plumaeforme) in the Nanling Mountains and the Pearl River Delta, Southern China. Atmos. Environ. 39: 397-407. https://doi.org/10.1016/j. atmosenv.2004.09.067

Li, J., Pan, J., Wen, F. and Chen, L. (2013). Calculation and analysis of aerosol residence times in atmosphere. Radiat. Prot. Bull. 33: 25-28. (in Chinese with English Abstract)

Liu, G., Tong, Y., Luong, J.H.T., Zhang, H. and Sun, H. (2010). A source study of atmospheric polycyclic aromatic hydrocarbons in Shenzhen, South China. Environ. Monit. Assess. 163: 599-606. https://doi.org/10.1007/s10661009-0862-4

Liu, G., Luo, Q., Ding, M. and Feng, J. (2015). Natural radionuclides in soil near a coal-fired power plant in the high background radiation area, South China. Environ. Monit. Assess. 187: 356. https://doi.org/10.1007/s10661015-4501-y

Liu, H., Jacob, D.J., Bey, I. and Yantosca, R.M. (2001). Constraints from ${ }^{210} \mathrm{~Pb}$ and ${ }^{7} \mathrm{Be}$ on wet deposition and transport in a global three-dimensional chemical tracer model driven by assimilated meteorological fields. $J$. Geophys. Res. 106: 12109-12128. https://doi.org/10.102 9/2000JD900839

Liu, J., Li, J., Zhang, Y., Liu, D., Ding, P., Shen, C., Shen, K., He, Q., Ding, X. and Wang, X. (2014). Source apportionment using radiocarbon and organic tracers for $\mathrm{PM}_{2.5}$ carbonaceous aerosols in Guangzhou, South China: Contrasting local-and regional-scale haze events. Environ. Sci. Technol. 48: 12002-12011. https://doi.org/10.1021/e s503102w

McNeary, D. and Baskaran, M. (2003). Depositional characteristics of ${ }^{7} \mathrm{Be}$ and ${ }^{210} \mathrm{~Pb}$ in southeastern Michigan. J. Geophys. Res. 108: 4210. https://doi.org/10.1029/2002 JD003021

Momoshima, N., Nishio, S., Kusano, Y., Fukuda, A. and Ishimoto, A. (2006). Seasonal variations of atmospheric ${ }^{210} \mathrm{~Pb}$ and ${ }^{7} \mathrm{Be}$ concentrations at Kumamoto, Japan and their removal from the atmosphere as wet and dry depositions. J. Radioana. Nucl. Chem. 268: 297-304. https://doi.org/10.1007/s10967-006-0181-y

Olsen, C.R., Larsen, I.L., Lowry, P.D., Cutshall, N.H., Todd, J.F., Wong, G.T.F. and Casey, W.H. (1985). Atmospheric fluxes and marsh-soil inventories of ${ }^{7} \mathrm{Be}$ and ${ }^{210} \mathrm{~Pb}$. J. Geophys. Res. 90: 10487-10495. https://doi.org/ 10.1029/JD090iD06p10487

Pan, J., Yang, Y.L., Zhang, G., Shi, J.L., Zhu, X.H., Li, Y. and $\mathrm{Yu}$, H.Q. (2011). Simultaneous observation of seasonal variations of beryllium-7 and typical POPs in nearsurface atmospheric aerosols in Guangzhou, China. Atmos. Environ. 45: 3371-3380. https://doi.org/10.1016/ j.atmosenv.2011.03.053 
Rastogi, N. and Sarin, M.M. (2008). Atmospheric ${ }^{210} \mathrm{~Pb}$ and ${ }^{7} \mathrm{Be}$ in ambient aerosols over low- and high-altitude sites in semiarid region: Temporal variability and transport processes. J. Geophys. Res. 113: D11103. https://doi.org/ 10.1029/2007JD009298

Renfro, A.A., Cochran, J.K. and Colle, B.A. (2013). Atmospheric fluxes of ${ }^{7} \mathrm{Be}$ and ${ }^{210} \mathrm{~Pb}$ on monthly timescales and during rainfall events at Stony Brook, New York (USA). J. Environ. Radioact. 116: 114-123. https://doi.org/10.1016/j.jenvrad.2012.09.007

Sarri, H.K., Schmidt, S., Castaing, P., Blanc, G., Sautour, B., Masson, O. and Cochran, J.K. (2010). The particulate ${ }^{7} \mathrm{Be} /{ }^{210} \mathrm{~Pb}_{\mathrm{xs}}$ and ${ }^{234} \mathrm{Th} /{ }^{210} \mathrm{~Pb}_{\mathrm{xs}}$ activity ratios as tracers for tidal-to-seasonal particle dynamics in the Gironde Estuary (France): Implications for the budget of particleassociated contaminants. Sci. Total. Environ. 408: 4784 4794. https://doi.org/10.1016/j.scitotenv.2010.07.017

Tan, K.Y., Yang, Y.L., Zhu, X.H., Chen, S., Jiao, X.C., Gai, N. and Huang, Y. (2013). Beryllium-7 in near-surface atmospheric aerosols in mid-latitude (40 degrees $\mathrm{N}$ ) city Beijing, China. J. Radioanal. Nucl. Chem. 298: 883-891. https://doi.org/10.1007/s10967-013-2524-9

Todd, J.F., Wong, G.T.F., Olsen, C.R. and Larsen, I.L. (1989). Atmospheric depositional characteristics of beryllium-7 and lead-210 along southeastern Virginia coast. J. Geophy. Res. 94: 11106-11116. https://doi.org/ 10.1029/JD094iD08p11106

Turekian, K.K, Benninger, L.K. and Dion, E.P. (1983). ${ }^{7} \mathrm{Be}$ and ${ }^{210} \mathrm{~Pb}$ total deposition fluxes at New Haven Conneticut and at Berbuda. J. Geophy. Res. 88: 5411-5415. https://doi.org/10.1029/JC088iC09p05411

Wang, N., Zheng, L., Chu, X., Li, S. and Yuan, S. (2016). The characteristics of radon and thoron concentration from soil gas in Shenzhen City of Southern China. Nukleonika 61: 315-319. https://doi.org/10.1515/nuka2016-0052

Winkler, R. and Rosner, G. (2000). Seasonal and long-term variation of ${ }^{210} \mathrm{~Pb}$ concentration in air, atmospheric deposition rate and total deposition velocity in South Germany. Sci. Total Environ. 263: 57-68. https://doi.org/10.1016/s0048-9697(00)00666-5

Yadav, A.K., Kumar, K., Kasim, A., Singh, M.P., Parida, S.K. and Sharan, M. (2003). Visibility and incidence of respiratory diseases during the 1998 haze episode in Brunei Darussalam. Pure Appl. Geophys. 160: 265-277. https://doi.org/10.1007/s00024-003-8777-4

Yang, Y., Gai, N., Geng, C., Zhu, X., Li, Y., Xie, Y., Yu, H. and Tan, K. (2013). East Asia monsoon's influence on seasonal changes of beryllium-7 and typical POPs in nearsurface atmospheric aerosols in mid-latitude city Qingdao, China. Atmos. Environ. 79: 802-810. https://doi.org/10.1 016/j.atmosenv.2013.07.021

Yi, Y., Zhou, P. and Liu, G. (2007). Atmospheric deposition fluxes of ${ }^{7} \mathrm{Be},{ }^{210} \mathrm{~Pb}$ and ${ }^{210} \mathrm{Po}$ at Xiamen, China. $J$. Radioanal. Nucl. Chem. 273: 157-162. https://doi.org/10. 1007/s10967-007-0728-6

Zhang, F., Zhang, B. and Yang, M. (2013). Beryllium-7 atmospheric deposition and soil inventory on the northern Loess Plateau of China. Atmos. Environ. 77: 178-184. https://doi.org/10.1016/j.atmosenv.2013.05.002

Zhang, L., Yang, W., Chen, M., Wang, Z., Lin, P., Fang, Z., Qiu, Y. and Zheng, M. (2016). Atmospheric deposition of ${ }^{7} \mathrm{Be}$ in the southeast of China A case study in Xiamen. Aerosol Air Qual. Res. 16: 105-113. https://doi.org/10.42 09/aaqr.2015.03.0182

Zhu, J. and Olsen, C.R. (2009). Beryllium-7 atmospheric deposition and sediment inventories in the Neponset River estuary, Massachusetts, USA. J. Environ. Radioact. 100: 192-197. https://doi.org/10.1016/j.jenvrad.2008.11.013

Received for review, November 5, 2019

Revised, February 24, 2020 Accepted, February 27, 2020 